\title{
高密度プラズマのバイオデバイス テクノロジーへの応用*
}

Application of High-density Plasmas in Biodevice Technology

\section{一木隆範** \\ Takanori ICHIKI}

Key words plasma etching, microfabrication, biodevice, $\mu \mathrm{TAS}$, microfluidic device

\section{1. はじめに}

リソグラフィー技術と並んで半導体微細加工の二大基盤 技術として高度に発達してきたドライエッチング技術は今 や半導体産業のみならず, MEMS (microelectromechanical system)をはじめ様々な技術分野に展開されつつある.数 $\mathrm{cm}$ 角のチップ上に微小なリアクターや流体制御素子を集 積化し, 微量な生体試料の操作, 分析を可能にするバイオデ バイス(ここでは $\mu \mathrm{TAS}$ (マイクロ化学分析システム), Lab-on-a-chip, バイオ MEMS などを指す)も, 半導体微細 加工技術の異分野展開の代表的な例である ${ }^{1) ~ 3) . ~}$

1990 年代末に多くの研究者の注目を集めた核酸塩基配 列解析用のマイクロキャピラリー電気泳動チップは数 10 100 $\mu \mathrm{m}$ 幅の微小流路を形成したガラスチップであり， フォトリソグラフィーやウエットエッチングを用いて製造 が可能であった4) 。 その後, バイオデバイスはゲノム解 析に加えて, プロテオーム解析, さらには細胞操作・計測 などその適用対象を拡張しつつ, 発展を続けている。 ま た，分析作業の自動化や高スループット化のために，試料 の前処理も含めた複数の分析作業モジュールを同一のチッ プ上に集積化する方向に進みつつある。デバイスに高度な システム機能が要求されるに伴い, チップ上の要素デバイ スであるマイクロ流体デバイスやセンサーの設計も次第に 複雑化, 多様化する。したがって, 高精度で自由度の高い 微細加工技術の重要性がますます大きくなっている。この ような背景のもとバイオデバイス製造に打ける高密度プラ ズマ応用について, ガラス基板のディープエッチング技術 を中心に紹介する。

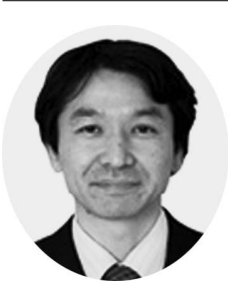

*原稿受付 平成 19 年 7 月 30 日

**東京大学大学院工学系研究科バイオエンジニア リング専攻（東京都文京区弥生 2-11-16) 一木隆範

1995 年東京大学大学院工学系研究科博士課程修 了. 博士 (工学). 東洋大学工学部電気電子工 学科助教授等を経て, 2004 年に東京大学大学院 工学系研究科総合研究機構助教授. 2006 年より 同研究科バイオエンジニアリング専攻准教授. 専門はバイオデバイス，プラズマ応用.

\section{2. バイオデバイスの基板材料}

バイオ分析においては蛍光検出や顕微イメージングなど 光学的手法によりチップ内部を計測することが多いため, ガラス，プラスチックなどの透明基板材料が多く用いられ る. ガラス材料は化学的安定性や耐熱性, 機械的強度, 光 学的特性に優れており， $\mu \mathrm{TAS}$ 研究ではその初期から広く 用いられてきた。一方, 医療診断チップなど使い捨てが好 ましい用途では, 射出成形（あるいはホットエンボス加 工）による量産と焼却廃書の可能なプラスチックが望まし いとされるが, 数 $10 \mu \mathrm{m}$ 以下の微細形状を形成しょうと すると通常の射出成形技術では困難である. また，光学的 ひずみの問題を克服しょうすると高価な材料を用いざるを えないなど技術的な課題が残る。また, 最近は精密鋳型に 流し込むだけで微細流路を転写でき, 接着性にも優れたポ リジメチルシロキサンと呼ばれる透明エラストマー材料が バイオデバイスの試作によく用いられている ${ }^{6)}$ それぞれ の基板材料に一長一短があるが, ガラスは, 熱的, 化学的 に安定なため半導体製造プロセスの応用が容易であり, プ ラズマ微細加工技術や配線技術を利用して機能性に優れた デバイスを実現できることが最大の特徴である。 バイオ分 析デバイスが対象とするモノの寸法は, DNA(螺旋径 2 $\mathrm{nm}$ )からタンパク質やウイルス(数 10 数 $100 \mathrm{~nm}$ ), 細胞 (数 $\mu \mathrm{m}$ )まで 4 桁程度にわたる. ドライエッチング技術を 用いると,ガラス基板上に $\mathrm{nm}$ から $100 \mu \mathrm{m}$ レベルまでの 広いサイズ領域にわたる精密加工が可能であり, 例えば $100 \mathrm{~nm}$ 級の微細構造をもつ流路内にDNA を流して DNA のサイズ分離を可能にしたデバイスの開発事例がある7).

\section{3. マイクロ流体デバイス作製プロセス}

ガラス基板上へのマイクロ流体デバイス作製の例として, 石英ガラス製マイクロキャピラリー電気泳動チップの作製 プロセスとチップ写真を図 1 に示す.ガラスウエファ上に Crメタルマスクと高密度プラズマを用いたディープドライ エッチング技術によりキャピラリー溝を形成した後, 残留マ スクをウエットエッチングにより除去する.最後に, 超音波 


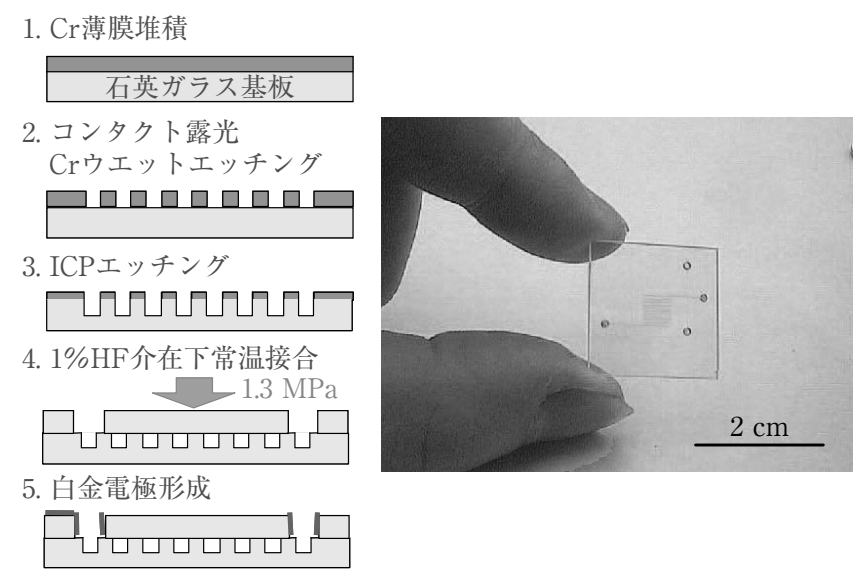

図 1 石英ガラス製マイクロ流体デバイスとその作製プロセス

加工によって緩衝液や試料の注入, 排出孔となる貫通孔を設 けた同じ大きさのガラスウエファを別に用意し,キャピラリ 一溝を形成したガラスウエファと重ね合わせて接合し,流路 を密閉する.接合はマイクロ流体デバイス作製において流路 の微細加工と並んで重要な要素技術であり, 高温炉中で融着 させる方法や, 石英ガラスの場合にはフッ酸を利用した室温 接合が用いられている ${ }^{8}$. 後者は 2 枚の石英ウエファ間に $1 \%$ のフッ酸を介在させて室温で $1.3 \mathrm{MPa}$ の荷重下で 24 時 間密着させると石英ウエファ表面で酸化ケイ素の溶解, 析出 が起こる結果, 接合が起こると考えられている.石英ガラス 以外にもホウ珪酸ガラス (Corning\#7740)加工用のディープ ドライエッチングプロセスも開発されており,ドライ加工に よる流路加工と陽極接合技術を用いることで図 2 に示すよ うに多層マイクロ流体デバイスの短時間作製も可能になっ た ${ }^{9)}$.また, LSI 配線技術を応用してマイクロ流体デバイスに 微小電極を組み込むことで, 電気(化学)計測や誘電泳動, 電 気泳動などの非接触外力による細胞操作の機能を付与する ことも可能になっている1011).

\section{4. 低圧高密度プラズマを用いたガラスのディープ エッチング}

\section{1 石英ガラスのディープエッチング}

高純度石英ガラスはガラス材料の中でも特に化学的安定 性に優れる。また，紫外域まで光透過性が高く，自家蛍光 も極めて低いことから，微量物質を光学的に高感度検出す ることが必要な場合には最も優れた基板材料である8). $\mathrm{SiO}_{2}$ エッチングは ULSI 多層配線に打ける絶縁層の微細 溝/孔加工に必要であるため長年に渡る厐大な量の研究成 果の蓄積があるが，この場合のエッチ深さは高々 $2 \mu \mathrm{m}$ 程 度である，光導波路などのマイクロ光学デバイスの作製で は $10 \mu \mathrm{m}$ 程度の深さが要求され，プラズマエッチングも 適用されているが1213)，マイクロ流体デバイスの作製では さらに深い $10 \sim 100 \mu \mathrm{m}$ の加工も必要である。したがっ て，より速いエッチング速度とより高い対マスク選択比の 実現が要求されるため, メタルマスクと高密度プラズマを 用いた石英の深堀加工技術が検討されている ${ }^{14)}$.

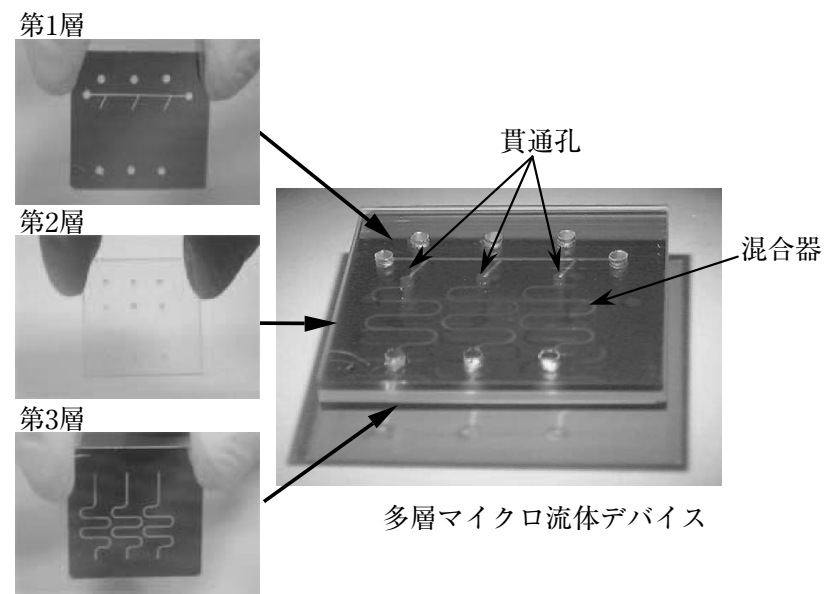

図 2 ホウ珪酸ガラス製積層マイクロ流体デバイスとその作製プロ セス

ここでは，フッ素を多く解離できる $\mathrm{SF}_{6}$ に $\mathrm{C}_{4} \mathrm{~F}_{8}$ を混合 した高密度プラズマを用い, さらに Cr 膜をメタルマスク として採用したプロセスについて記す。内径 $100 \mathrm{~mm}$ の石 英ベルジャー内に一巻のアンテナを介し， $13.56 \mathrm{MHz}$ の高 周波電力を印加して誘導結合プラズマを発生させ，ガラス 基板にもその表面に有効な自己バイアス電圧を生じさせる ために $13.56 \mathrm{MHz}$ の高周波を印加した。 $\mathrm{C}_{4} \mathrm{~F}_{8}$ は側壁保護 膜の形成によって垂直加工形状を得るために加えるが，フ ルオロカーボン重合膜の形成は, プラズマ反応器内部の温 度変化により変動しやすいため, ヒーターや水冷機構を装 置に付与して温度を管理する必要がある。フルオロカーボ ンプラズマによるシリコン酸化膜のエッチングでは $\mathrm{SiF}_{4}$ と $\mathrm{CO}_{2}$ が生成することがよく知られており，ともすれば 炭素による還元反応が酸化膜エッチングでは不可欠と勘違 いしがちであるが， $\mathrm{C}_{4} \mathrm{~F}_{8}$ の添加による還元反応がなくて も，高速エッチングは可能である． $\mathrm{SF}_{6}$ のみを用いる条件 では基板上に斜めに入射するイオンの存在により，逆テー パー形状になってしまうため垂直性エッチングが達成でき ず， $\mathrm{C}_{4} \mathrm{~F}_{8}$ の添加による側壁保護が必要であった． ICP 電 力 $500 \mathrm{~W}$, 基板電力密度 $4 \mathrm{~W} / \mathrm{cm}^{2}$, 圧力 $10 \mathrm{mTorr}$ で行っ たエッチング実験では, $\mathrm{C}_{4} \mathrm{~F}_{8} / \mathrm{SF}_{6}$ の混合比が $85 / 15$ の条 件で選択比 80（マスク肩口での選択比は 25）で石英のエ ッチング速度 $530 \mathrm{~nm} / \mathrm{min}$ が得られた。この条件で約 1.6 $\mu \mathrm{m}$ の厚さの $\mathrm{Cr}$ マスクを用いて図 3 の断面 SEM 写真に 示すように深さ $50 \mu \mathrm{m}$, 幅 $20 \mu \mathrm{m}$, アスペクト比 2.5 の垂 直ディープエッチングが達成された。

\section{2 ホウ珪酸ガラスのディープエッチング}

ホウ珪酸ガラスのなかでもコーニング 7740 はシリコン と熱膨張係数が等しく，陽極接合 ${ }^{15}$ が可能なためマイクロ マシン材料としてしばしば用いられる。ホウ珪酸ガラス は，成分中に含まれる $\mathrm{Al}$ や $\mathrm{Na}$ などの金属元素のフッ化 物が不揮発性であるためにエッチング表面にマイクロマス クを生じ，芝生（grass）のように細く尖った無数の突起 形状が形成されやすい(16) 18). この残留フッ化物は高エネ ルギーイオン衝撃により物理的に除去できるが，高エネル 


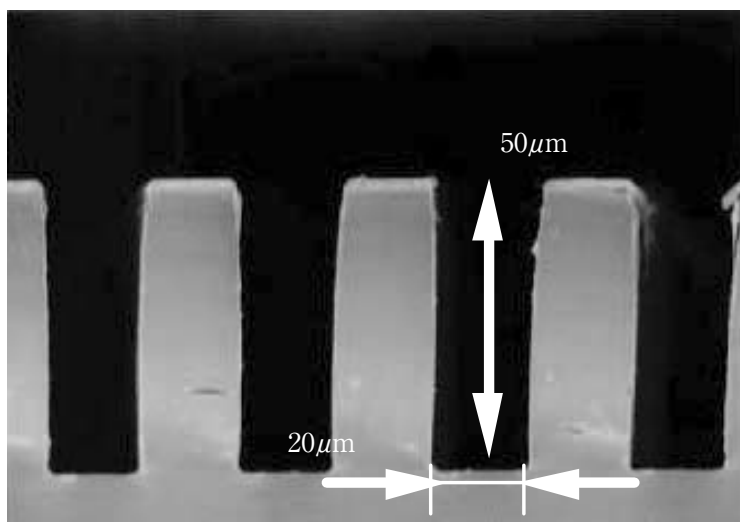

図 3 石英ガラスの垂直ディープトレンチ加工の例

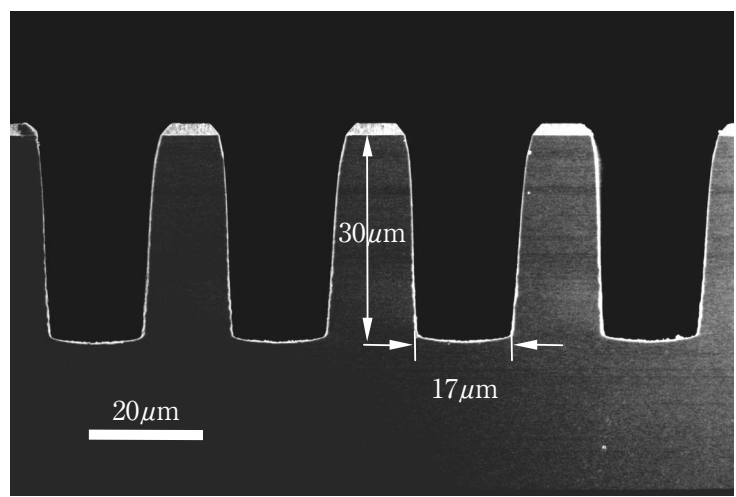

図4 ホウ珪酸ガラスのディープトレンチ加工の例

ギーイオン衝撃下のエッチングではマスク選択比の低下が 問題になる。 そこで， $\mathrm{SF}_{6}$ に $\mathrm{Ar}$ を添加してエッチングを 行ったところ，Arイオンによるフッ化物のスパッ夕除去 が効果的に抗こるため，比較的低エネルギーのイオン衝撃 下でもエッチング表面が平坦になり，高マスク選択比を得 ることができたＡＡr 50\%の条件下で，40に近いマスク選 択比が得られ，図 4 に示すような幅 $17 \mu \mathrm{m}$, 深さ $30 \mu \mathrm{m}$ のデイープドライエッチングが達成されている17)。

\section{5. プラズマ微細加工によるデバイス試作例}

ドライエッチングによる高アスペクト比加工の利点を用 いたマイクロ流体デバイスの試作例を幾つか挙げる．図 5 は石英ガラスの高アスペクト比加工技術を利用して試作し たマイクロミキサーデバイスである ${ }^{19)}$ 。溶液の混合は，攪 拌による異なる液相間の境界面の増大と異相間での溶質の 拡散の 2 段階の過程で進行する。ところが，数 10〜100 $\mu \mathrm{m}$ スケールのマイクロ流路内では溶液のレイノルズ数が 小さいため乱流による攪拌が事実上困難になる。このた め, 強制的に異なる液相間の境界面の増大を促す要素デバ イス，すなわちマイクロミキサーが必要になる。図 5 右 上図は顕微鏡明視野像，右下図は蛍光像であり，蛍光試薬 が迅速に混合されている様子が分かる．2枚のガラス上に $150 \mu \mathrm{m}$ 幅の流路の一部を 15 本に分枝した箇所を形成して おき，位置合わせして貼り合わせると交差部に 225 個の $10 \mu \mathrm{m}$ 角のマイクロノズルアレイが形成される．分枝流路

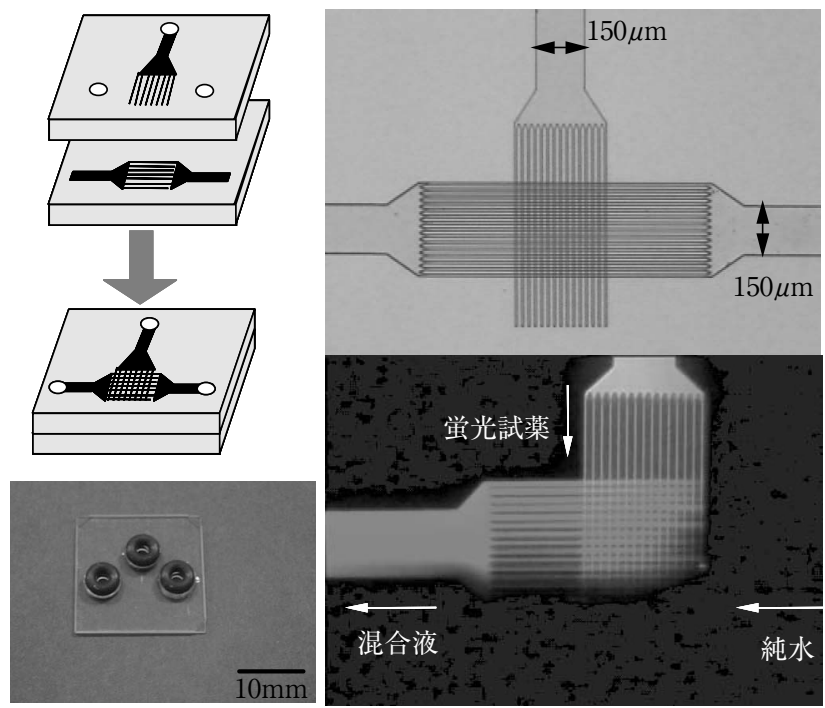

図 5 石英ガラス製マイクロミキサー

を高アスペクト比形状で形成することでこのマイクロノズ ルアレイからの試液の噴出が均一化され，優れた混合効率 が得られている。

図 6 は任意細胞の個別分取を可能にするセルソーター デバイスである ${ }^{11}$. 同図の左上に示すようにデバイスは細 胞導入用流路とシースフロー形成用流路，その下流に位置 する一対の埋め込々電極で挟まれた細胞収集用流路とその 両側に位置する廃棄用流路からなる。シースフローを形成 することにより細胞を効率よく収集用流路口に送り込み， 電極に交番電界を印加して生じる反発性誘電泳動力によ り，不必要な細胞のみを廃棄することができる（同図下）.

微細構造体による細胞の直接的計測，操作（細胞内外へ の物質抽出, 注入, 細胞内あるいは細胞膜の電位計測な ど）の概念を実装化するために，図７に示す自己支持型 シリカ製マイクロニードルのマイクロ流体デバイスへの集 積化 ${ }^{20)}$ や，図 8 に示すシリカ製プレーナー型マイクロピペ ットデバイス ${ }^{21}$ が試作されている，前者を作製するために 開発された製造プロセスは，ピペットを自立構造にするた めの犠牲層となるアモルファスシリコン層を用い，さらに ホウ珪酸ガラス基板との陽極接合に利用する点に特徵があ る。流路，マイクロニードルはいずれも可視光域で透明 で，顕微鏡下での細胞観察，レーザーピンセットとの併用 に適している。ママイクロ流路により細胞を自動的にマイク ロピペット先端位置に輸送できること, 約 $1 \sim 2 \mu \mathrm{m}$ 径の シリカガラス製マイクロニードルが細胞膜を容易に貫通す ることが確認された（図 7 右下図）。後者については，厚 さ $150 \mu \mathrm{m}$ の溶融石英ガラスに両面からそれぞれ径が 100 $\mu \mathrm{m}, 2 \mu \mathrm{m}$ の孔をアライメントしてプラズマエッチング加 工を施し，細胞膜の一部をクランプして電流を流すための 貫通孔を形成し，ポリマー製マイクロ流体デバイスに組み 込んで用いた，マイクロピペットデバイスの電気的等価回 路を評価した結果，試作チップは従来より用いられている ガラス管を引き伸ばして作製するマイクロ電極と同程度の 

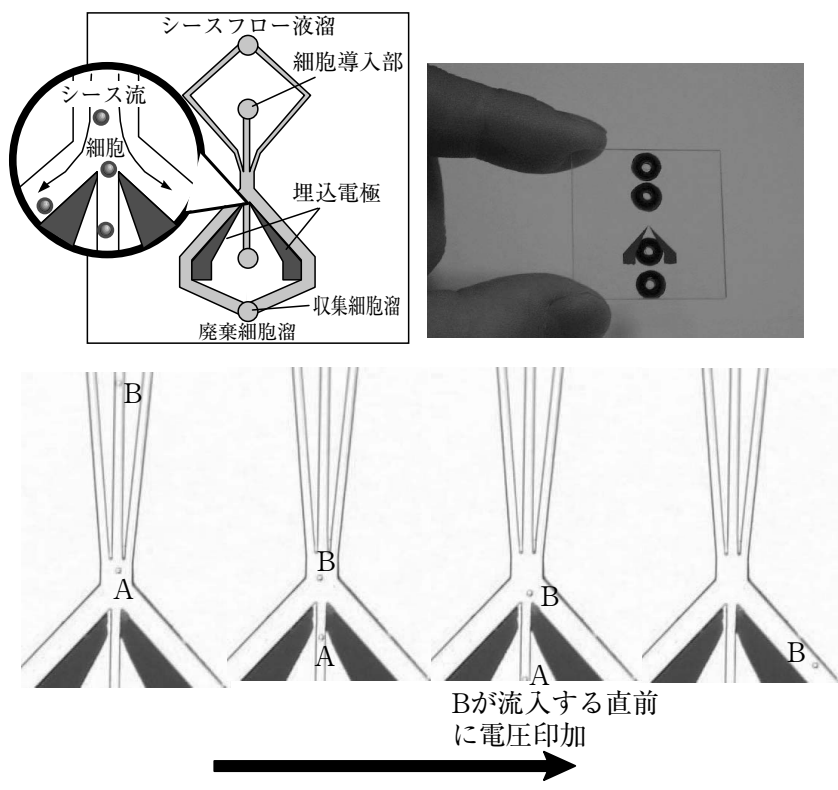

図 6 誘電泳動方式セルソーターデバイス

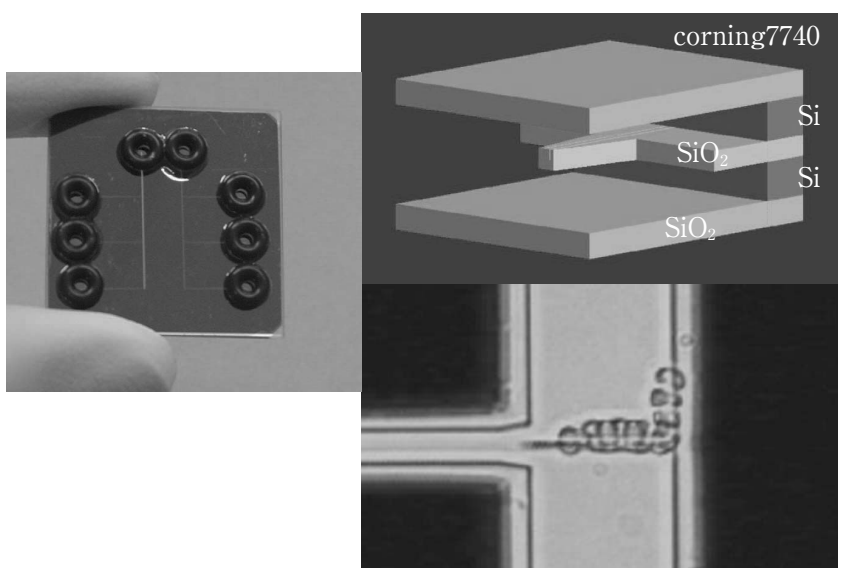

図 7 流路内に集積化した自立型シリカニードル

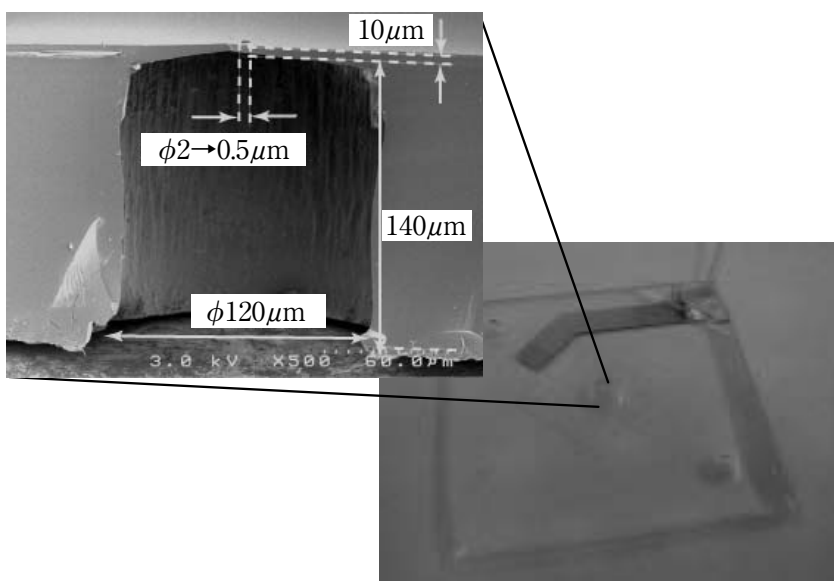

図 8 石英ガラスのディープエッチングにより加工したプレーナー パッチクランプ電極とこれを集積化した細胞電気生理計測用 デバイス

良好な性能を有することが確認された。

\section{6. ま と め}

半導体産業で培われた高密度プラズマエッチング技術バ
イオデバイス製造への応用について紹介した，バイオデバ イスを研究する多くの者にとっては, 装置の導入コストや 少なからぬノウハウが必要とされることが主な理由で, 高 密度プラズマプロセス技術はまだまだ高嶺の花というのが

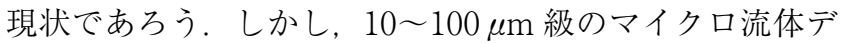
バイス, マイクロリアクターによる生体試料の輸送や操作 にとどまらず， $\mu \mathrm{m}$ サブ $\mu \mathrm{m}$ 級の微細構造デバイスを利 用することで 1 細胞を局所的に計測することが可能にな り,さらにサブ $\mu \mathrm{m} \sim \mathrm{nm}$ 級の極微細構造を利用したデバ イスにより生体分子の直接的な計測までが可能になる。高 密度プラズマエッチングは, 高機能バイオデバイスの実現 に不可欠な基盤技術であり，今後，ますますの当該分野へ の普及と貢献が期待される。

\section{参 考 文 献}

1）江刺正喜 監修：マイクロマシン，産業技術サービスセンター, 東京, (2002).

2) 松永是 監修: バイオチップの最新技術と応用, シーエムシー出 版, 東京, (2004).

3）堀池靖浩, 宮原祐二：バイオチップとバイオセンサー, 共立出 版, 東京, (2006)

4) A.T. Woolley, G.F. Sensabaugh and R.A. Mathies : Anal. Chem., 69 (1997) 2181.

5) Y.N. Shi, P.C. Simpson, J.R. Scherer, D. Wexler, C. Skibola, M.T. Smith and R.A. Mathies: Anal. Chem., 71 (1999) 5354.

6) D.C. Duffy, J.C. McDonald, O.J.A. Schueller and G.M. Whitesides: Anal. Chem., 70 (1998) 4974.

7) N. Kaji, Y. Tezuka, Y. Takamura, M. Ueda, T. Nishimoto, H. Nakanishi, Y. Horiike and Y. Baba. : Anal. Chem., 76, 1 (2004) 15.

8) 中西博昭, 阿部浩久, 西本尚弘, 荒井昭博: 分析化学, 47 (1998) 361

9) T. Ichiki, Y. Sugiyama and Y. Horiike: J. Photopolymer, Sci. Technol., 15, 2 (2002) 311.

10) T. Ichiki, S. Shinbashi, T. Ujiie and Y. Horiike : J. Photopolymer, Sci. Technol., 15, 3 (2002) 487.

11) T. Ichiki, T. Ujiie, T. Hara, Y. Horiike and K. Yasuda : Micro Total Analysis Systems 2001, Kluwer Academic Publishers, Netherland, (2001) 119.

12) M.V. Bazylenko and M. Gross, J. Vac. Sci. Technol., A14 (1996) 2994.

13) K.J. An, D.H. Lee, J.B. Yoo, J. Lee and G.Y. Yeom: J. Vac. Sci. Technol., A17 (1999) 1483.

14） T. Ujiie, T. Kikuchi, T. Ichiki and Y. Horiike : Jpn. J. Appl. Phys., 39 (2000) 3677

15) G. Wallis : J. Appl. Phys., 40, 3946 (1969).

16) X. Li, T. Abe and M. Esashi: Proceedings of Micro Electro Mechanical Systems 2000, Miyazaki, Japan, (2000) 271.

17) T. Ichiki, Y. Sugiyama, T. Ujiie and Y. Horiike: J. Vac. Sci. Technol., B21 (2003) 2188.

18) T. Ichiki, Y. Sugiyama, R. Taura, T. Koidesawa and Y. Horiike : Thin Solid Films, 435 (2003) 62.

19) T. Ichiki, M. Watanabe, Y. Sugiyama and Y. Horiike : Abstr Microprocessess and Nanotechnology 2002, Tokyo, (2002) 292.

20) T. Ichiki, Y. Sugiyama, S. Kase and Y. Horiike: Micro Total Analysis Systems 2003, Kluwer Academic Publishers, Netherlands, (2003) 1025.

21）赤木貴則，南野淳，一木隆範：電気学会論文誌，126-C (2006) 730. 